\title{
Management accounting instruments as a security engineering tools used in solving crisis problems
}

\author{
Anna KUCZYŃSKA-CESARZ *1 \\ ${ }^{1}$ Military University of Technology, Warsaw, Poland
}

\begin{abstract}
Managing organizations means taking lots of decisions based on information contained mainly in the accounting books and financial statements. The processing of this information for decision-making purposes is the domain of management accounting, offering managers a number of decision-making tools described in this article to help overcome difficulties (threats), also known as crisis situations. From the presented management tools (security engineering tools) budgeting with attention to the creation of a budget in the enterprise (traditional budget and budget based on activity-based costing) and task-based budget in public finance sector units has been characterized. Both budgets were compared, taking into account common features. The comparison shows that budgeting based on activity-based costing and task-based budgeting are instruments combining goals with the tasks of the organization and the efficiency of using the resources available.
\end{abstract}

Keywords: security engineering, management instruments, management accounting, budgeting, performance budget.

\section{Introduction}

Entities operating in the Polish economy, both conducting economic activity and operating in the public finance sector, encounter situations often referred to as crisis situations or situations related to overcoming difficulties (threats) in achieving their goals. Threats to a person, his achievements and the environment have always existed. With the development of civilization and techniques, some of them lost their importance or disappeared, and new ones appeared instead, escalating and becoming more and more burdensome. From the very beginning of his existence, a human being had to face them which he did not deal with satisfactorily or could not cope with their effects. Awareness of the occurrence of threats and their recognition allows for their prediction and estimation of undesirable effects, and this is a small, although sometimes very complicated and difficult step to protect against it, counter or minimize their effects (...). The threats forced the emergence of a new direction in science, which is security engineering (...). The issues of safety engineering of anthropogenic objects focus on the practical areas of ensuring safety in various processes implemented for and with the participation of people [1].

For example, such an area is management accounting, which provides a number of solutions ensuring the security of business activity, especially in crisis situations (threats). It should be clearly emphasized that the threats may concern all anthropogenic objects, that is 'objects generated by man to satisfy his needs. Material and non-material resources are necessary to meet the needs. There are certain relationships between needs and resources. These relations are dealt with by economics, which seeks answers to the age-old question: how to satisfy unlimited needs with limited resources $^{6}[9]$.

Threats in running a business in the area of financial management usually cause disruptions in various areas of an organization's life, manifested, for example, in the lack of financial liquidity, excessive indebtedness, decrease in turnover, deterioration of economic and financial indicators, defective control, etc .Basic source of information enabling the evaluation of threats and the current economic and financial situation of the organization is its financial statement, which is the final product of the accounting system (it is also an anthropogenic product). This system guarantees the reliability of data from financial statements if it is based on the current requirements of national and international

\footnotetext{
*Corresponding author: E-mail address: anna.cesarz@wat.edu.pl (Anna KUCZYŃSKA-CESARZ)
} 
balance sheet law, obliging all its recipients to strictly apply the legal regulations contained in the economic practice of a given country.

Processed numerical data confirmed with appropriate documents by the accounting system contained in the books of accounts of a given entity show changes in its assets, sources of its financing, revenues, costs and financial result during the financial year. They constitute the basis for the preparation of all components of the financial statements that allow to assess: the size and structure of assets and sources of its financing, the level of various categories of financial results having a major impact on the profitability of the business, cash flow in the area of operating, financial and investment activities that shape financial liquidity and changes in the amount of equity capital recognized as the main source of financing the business.

Creation of financial statements is the domain of financial accounting treated as external accounting that enables the entities to communicate with their environment. For management purposes, and mainly for the process of taking numerous long and short-term decisions, financial accounting is a source of data used by the management staff to build numerous budgets, analyse and control them, adjust the amounts included in the budgets, analyse the use of property resources and sources of financing these resources, the level of revenues, costs and financial result, analyse the level of profitability and financial liquidity.

In problematic (difficult, crisis) situations, managers use the available management accounting instruments, which often help to improve the economic and financial condition of the organization and protect it against bankruptcy or liquidation.

These instruments can be included in the security engineering tools that create a number of mechanisms to ensure the safety of all human products, i.e. broadly understood anthropogenic objects.

The aim of this article is to present the issues of selected management accounting instruments used in Poland, used in decision-making processes to improve the management system, both in enterprises and in units of the public finance sector.

$[4-7,10,13]$

\section{Management accounting and decision-making processes}

Accounting understood as a quantified measure of the financial situation and economic activity of the enterprise ... [11] faces a lot of tasks. One of them is the assessment of the unit's achievement in the past period - this is an area assigned to financial accounting, the other is to plan what should be done in the near and distant future - this area is assigned to management accounting. The tasks of both areas of accounting fall within the scope of widely understood financial management of the entity, as shown in fig. 1.

All activities falling within the scope of financial accounting and management accounting are complementary to each other, although the extent of usefulness of the information provided by the financial accounting system differs for both areas.

Source: Peterson R., Kompendium terminów z zakresu rachunkowości po polsku i angielsku, mf.gov.pl, Warsaw 2015, p. 378 .

The differences in the perception of financial and management accounting are presented in fig. 2.

Source: own study.

Management accounting is a system of gathering, processing and presenting the obtained information relating to past and future economic phenomena in order to support the company's management in planning, organizing, employing, managing and controlling [12]. Management accounting deals with many decision-making problems. For example, they may concern the following situations in organizations [3]:

- maintaining financial liquidity,

- controlling the circulation of working assets,

- controlling the economics of fixed assets,

- cost control,

- calculation, price decisions and planning of profits from projects, 


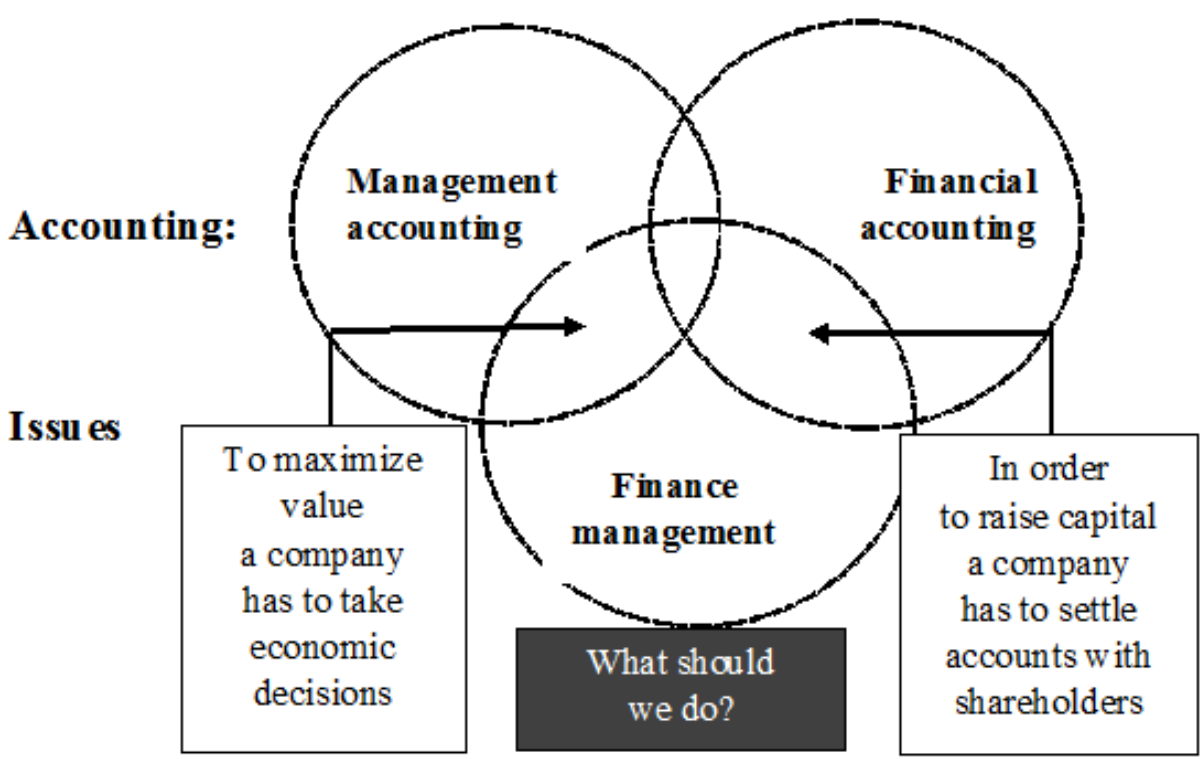

Figure 1. Issues of financial and management accounting

\section{ACCOUNTANCY}

\section{Financial accounting}

- is external accounting

- the financial statement allows for communication with the external environment

- is based on the past

- complies with national and international law

- characterised by reliability, credibility, transparency, comparability

\section{Management accounting}

- is internal accounting

- the financial statement and accounts provide information for management purposes

- is future-oriented

- is based on significant costs

- is made for managers internal needs

- is relevance, thrift, usefulness and functionality-oriented in the decisionmaking process

Figure 2. Financial accounting and management accounting

- production and sales policy,

- achieving a constant increase in efficiency and productivity,

- stimulating the crew's activity,

- reporting and preparation of reports for managers,

- solving specific decision problems,

- effective planning and control system.

As it can be seen, the scope of decision-making problems solved by management accounting is very wide and 
they concern various spheres of the organization's functioning. Each of the above-mentioned decision-making areas covers detailed problems that require identification, characterization, assessment of the role and impact on the further functioning of the unit. The decision-making problems in individual decision-making areas are presented in more detail in tab. 1.

The presented various decision-making problems are solved by management accounting instruments - tools of safety engineering of anthropogenic objects, based on accurate, selected and confirming the reality information. The carrier of this information is usually the financial accounting system, in particular accounting books and financial statements. How to read and understand the financial statements and entries in the books of accounts in order to obtain information for decision-making purposes is a huge challenge for managers. The analytical importance of financial statement elements for decision-makers in the decision-making process is shown in fig. 3.

Table 1. Selected decision problems and management accounting

\begin{tabular}{|c|c|}
\hline Decision-making areas & Decision problems \\
\hline $\begin{array}{l}\text { Maintaining financial liq- } \\
\text { uiditys }\end{array}$ & $\begin{array}{l}\text { Financial liquidity determines the entity's ability to pay its current liabilities and } \\
\text { the ability to purchase goods and services to operate. Maintaining financial liquidity } \\
\text { at an optimal level (not high and not too low) is a significant problem for managers. } \\
\text { When testing financial liquidity, an analysis of the relationship between current assets } \\
\text { and short-term liabilities should be performed. The most frequently used measures of } \\
\text { financial liquidity are current, quick and immediate liquidity, which allow to determine } \\
\text { the degree of solvency of current assets. }\end{array}$ \\
\hline $\begin{array}{l}\text { Controlling the circulation } \\
\text { of working assets }\end{array}$ & $\begin{array}{l}\text { The difference between current assets and short-term liabilities is the working capital } \\
\text { used as a measure of an entity's financial liquidity. The level of working capital is } \\
\text { influenced by many factors, the most important of which are the size and structure } \\
\text { of receivables, liabilities and inventories. }\end{array}$ \\
\hline $\begin{array}{l}\text { Controlling the economics } \\
\text { of fixed assets }\end{array}$ & $\begin{array}{l}\text { Decision-making problems in this area are related to the 'path of fixed assets from } \\
\text { acquisition to liquidation' and relate in particular to their initial and balance sheet val- } \\
\text { uation, cost shaping including depreciation, presentation in the financial statements, } \\
\text { recognition in accounting books and impact on the financial result }\end{array}$ \\
\hline Cost control & $\begin{array}{l}\text { The selection of the correct cost accounting for management purposes is the most } \\
\text { important decision-making problem in an organization. The cost accounting, corre- } \\
\text { sponding to the specificity of the conducted activity, allows to obtain, process and } \\
\text { apply information on costs, revenues and results in the decision-making process. The } \\
\text { essence of cost accounting is the measurement of the consumption of individual re- } \\
\text { sources. }\end{array}$ \\
\hline $\begin{array}{l}\text { Calculation, price deci- } \\
\text { sions, planning of profits } \\
\text { from ventures }\end{array}$ & $\begin{array}{l}\text { Shaping prices based on the selected calculation method and estimating profits from } \\
\text { planned projects are issues beyond the scope of cost accounting. Management ac- } \\
\text { counting provides managers with many methods of shaping the unit cost based on } \\
\text { traditional calculation methods and the activity-based costing method. The calcu- } \\
\text { lated unit cost is the basis for pricing models that allow to determine the selling price } \\
\text { of final products on the basis of gross margin, net margin, margin for coverage and } \\
\text { the rate of return on investment expenditure. }\end{array}$ \\
\hline $\begin{array}{l}\text { Production and sales pol- } \\
\text { icy }\end{array}$ & $\begin{array}{l}\text { It includes all managers }{ }^{6} \text { decisions regarding activities that allow to introduce new } \\
\text { products, maintain the continuation of profitable ones, cease production of unprof- } \\
\text { itable ones. Decision makers use various tools available in the entity's management } \\
\text { process, which includes planning, organizing, directing and controlling the use of hu- } \\
\text { man, financial, material and information resources }\end{array}$ \\
\hline $\begin{array}{l}\text { Achieving constant gains } \\
\text { in efficiency and produc- } \\
\text { tivity }\end{array}$ & $\begin{array}{l}\text { Productivity and efficiency are indicators for assessing the development of an or- } \\
\text { ganization. Measurement of the ratio of production to inputs, taking into account } \\
\text { the time spent on production, allows to assess the increase or decrease in efficiency } \\
\text { and productivity. In the current economic reality, not only the production volume is } \\
\text { important, but also its costs. }\end{array}$ \\
\hline
\end{tabular}


Table 1. Selected decision problems and management accounting

\begin{tabular}{|l|l|}
\hline Decision-making areas & Decision problems \\
\hline Crew activity stimulation & $\begin{array}{l}\text { It is related to the incentive system used in the organization, the remuneration policy } \\
\text { and the job evaluation system. Managers, using numerous economic and financial } \\
\text { indicators, can analyse the use of the human factor in achieving the goals of the unit. }\end{array}$ \\
\hline $\begin{array}{l}\text { Reporting and prepara- } \\
\text { tion of reports for man- } \\
\text { agers }\end{array}$ & $\begin{array}{l}\text { It includes activities aimed at providing managers with information in the form of } \\
\text { budgets specifying tasks to be performed and funds for their implementation, as well } \\
\text { as all types of result and control reports and internal reports enabling a comprehensive } \\
\text { assessment of the implementation of the assumed goals in the adopted time horizon. }\end{array}$ \\
\hline $\begin{array}{l}\text { Solving detailed decision } \\
\text { problems }\end{array}$ & $\begin{array}{l}\text { This area concerns the development of methods of assessing decision variants in un- } \\
\text { usual situations related to the changing external environment of the organization. }\end{array}$ \\
\hline $\begin{array}{l}\text { Effective planning and } \\
\text { control system }\end{array}$ & $\begin{array}{l}\text { Internal control and internal audit in a company, external audit, management control } \\
\text { in public finance sector units are control systems directly related to the management } \\
\text { processes of organizations. Although each of these systems has different tasks to } \\
\text { ful-fil, they are all important and complement each other, giving managers the oppor- } \\
\text { tunity to assess the degree of achievement of the goals set in the prepared plans. } \\
\text { Post-inspection conclusions and recommendations have an impact on a number of } \\
\text { activi-ties, thanks to which irregularities indicated by controllers and auditors are } \\
\text { corrected, which translates into the efficiency of using the assets entrusted to the } \\
\text { managers. }\end{array}$ \\
\hline
\end{tabular}
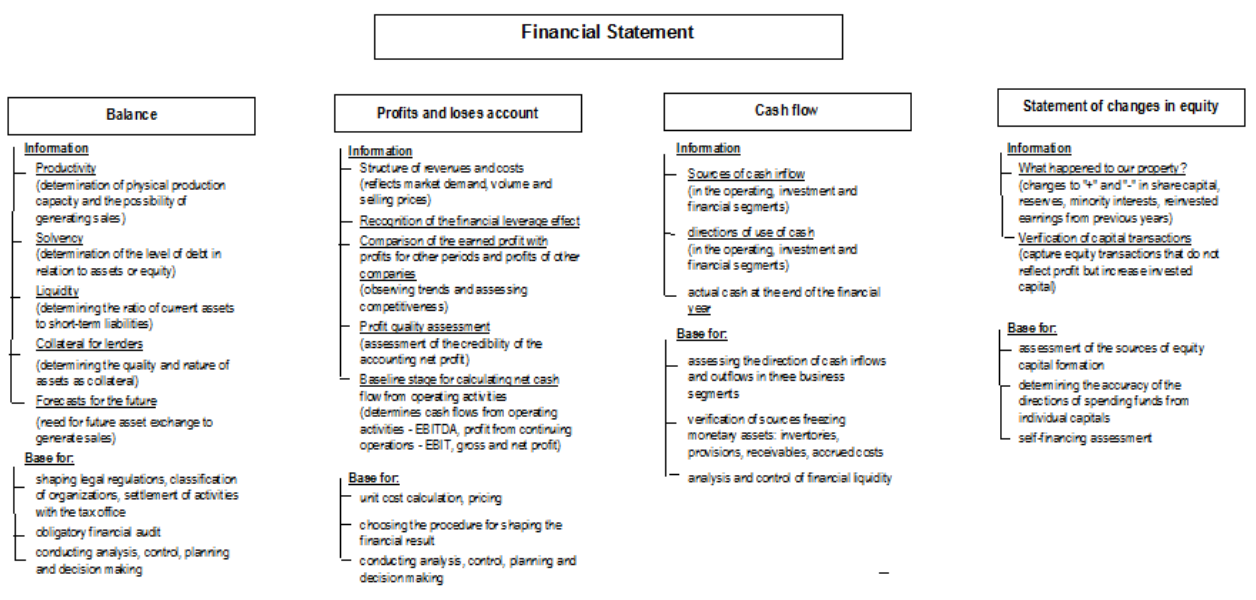

Figure 3. Analytical use of elements of financial statements in the decision-making process

Source: own study based on Peterson R., Kompendium terminów z zakresu rachunkowości po polsku i angielsku, mf.gov.pl, Warszawa 2015, pp. 50, 372, 375-376, 594 and Kuczyńska-Cesarz A., Rachunkowość kreatywna a bezpieczeństwo informacji zawartych w sprawozdaniu finansowym, Nowoczesne Systemy Zarządzania, Zeszyt 13 nr 1, Wojskowa Akademia Techniczna, Warszawa 2018, pp. 114-115.

\section{Management accounting tools used in solving crisis problems (threats)}

Can management accounting be considered an effective tool against the crisis? This question is raised by managers looking for solutions to difficult problems conditioning the further functioning of lots of organizations. The tool is effective if it approximates or ensures the achievement of a result consistent with the intended purpose. Due to the fact that there are numbers of instruments to improve the management process offered to managers by management accounting, they must be selected and properly matched to a specific decision problem, taking into account the specificity of a given entity's operations. 
It is well known that management accounting is a source of knowledge about costs and revenues, which, through the tools it describes, are used in various areas of factor management. Tab. 2 presents selected management accounting tools commonly used in practice in solving problematic management situations, with their short characteristics.

The management accounting tools presented in tab. 2 are used by the managers of business entities as well as entities belonging to the public finance sector. The choice of a specific instrument, preparation for implementation, application and control of its use depend on several factors, especially on the goal that the decision-makers intend to achieve.

Of the mentioned tools, budgeting is the universal one that is commonly used. In enterprises, this instrument is used both at the level of strategic and operational planning, as well as, for example, in a commune representing the public finance sector at the operational level, as performance budgeting.

Table 2. Characteristics of selected management accounting tools used in solving decision problems

\begin{tabular}{|c|c|}
\hline $\begin{array}{l}\text { Management account- } \\
\text { ing tool. }\end{array}$ & Characteristics and area of use \\
\hline Cost accounting & $\begin{array}{l}\text { Cost accounting is about examining and transforming, according to the adopted model } \\
\text { and standards, information on costs and revenues, past, current and intended activ- } \\
\text { ities in order to support the management of the entity. Cost accounting models*: • } \\
\text { traditional: full and variable costs, real, normal and postulated costs, } \bullet \text { other mod- } \\
\text { els: calculation of target costs, product life cycle, real costs, continuous improvement } \\
\text { costs. }\end{array}$ \\
\hline $\begin{array}{l}\text { Activity Based Costing - } \\
\text { ABC }\end{array}$ & $\begin{array}{l}\text { The } \mathrm{ABC}^{* *} \text { calculation is a method that allows to assign costs in a cause-and-effect } \\
\text { manner to final calculation objects, such as: products, services, customers. The main } \\
\text { purpose of using the } \mathrm{ABC} \text { account is to study profitability [15]. In this method } \\
\text { indirect costs are accounted for in separate activities generating resource costs. }\end{array}$ \\
\hline $\begin{array}{l}\text { Traditional methods of } \\
\text { calculating the unit cost }\end{array}$ & $\begin{array}{l}\text { The procedure of determining the actual cost of production per unit of calculation } \\
\text { and settlement of indirect costs (management and sales) is specified in the Polish } \\
\text { accounting law (the Accounting Act). This procedure is based on the reporting cost } \\
\text { accounting with the use of such methods as: simple division calculation, division ratio, } \\
\text { additional (commissioned), phase, combined products. Calculated unit cost is used } \\
\text { in pricing models to determine the unit selling price. }\end{array}$ \\
\hline $\begin{array}{l}\text { Instruments resulting } \\
\text { from the cost-production- } \\
\text { profit relationship analysis }\end{array}$ & $\begin{array}{l}\text { The cost-production-profit relationship analysis is the basis for the search for decision- } \\
\text { making solutions and answers to such research problems as: } \bullet \text { what volume of pro- } \\
\text { duction (sales) allows the unit to achieve the intended financial result, } \bullet \text { what part of } \\
\text { the realized sales revenues will remain to cover fixed costs and the planned profit, } \bullet \text { at } \\
\text { what volume of production (sales) the unit will reach the critical point corresponding } \\
\text { to the zero financial result, } \bullet \text { what margin of safety divides the unit from the critical } \\
\text { point in the current production (sale). The instruments used in this area include the } \\
\text { following indicators: production volume, selling price, level of fixed costs, variable } \\
\text { unit cost level, quantitative break-even point, value break-even point, coverage ratio, } \\
\text { certainty ratio, quantitative safety margin, valuable safety margin, operating leverage } \\
\text { ratio, profit ratio, monetary break-even rate. }\end{array}$ \\
\hline
\end{tabular}


Table 2. Characteristics of selected management accounting tools used in solving decision problems

\begin{tabular}{|c|c|}
\hline $\begin{array}{l}\text { Management account- } \\
\text { ing tool. }\end{array}$ & Characteristics and area of use \\
\hline $\begin{array}{l}\text { Price decisions - pricing } \\
\text { models }\end{array}$ & $\begin{array}{l}\text { The most common pricing models used by managers in their pricing decisions are } \\
\text { the economic model and the accounting model. The economic model seeks the profit- } \\
\text { maximizing price and is based on examining the relationship between the demand and } \\
\text { supply for a given product using the demand-elasticity price index. The accounting } \\
\text { model takes into account the dependence of the price on costs and distinguishes } \\
\text { detailed models based on: gross margin, net margin, coverage margin, method based } \\
\text { on the rate of return on capital. Each of the detailed models is based on a different } \\
\text { cost (production, total, variable), which has a direct impact on their use in short or } \\
\text { long-term decisions. Price models allow to calculate the price in the short term (at } \\
\text { the level of the unit variable cost) - short-term decisions, the minimum price in the } \\
\text { long run (it ensures the total unit cost coverage - the obtained result reaches the zero } \\
\text { level), the normal price in the long run (allows to achieve the desired profit). }\end{array}$ \\
\hline $\begin{array}{l}\text { Budgeting as an instru- } \\
\text { ment of management ac- } \\
\text { counting }\end{array}$ & $\begin{array}{l}\text { A budget treated as a plan for the use of an individual's resources in a specific time pe- } \\
\text { riod is a tool for effective management of the organization. Its creation and approval, } \\
\text { along with the control of the execution of tasks included in the budget, is referred to } \\
\text { as budgeting. Through budgeting, it is possible to: quantify tasks and goals, cooper- } \\
\text { ate, coordinate and communicate at various levels of the unit management, provide } \\
\text { information for the purposes of control in each area of the unit's operation, provide } \\
\text { knowledge about revenues, costs, financial result, fixed and current resources held, } \\
\text { amounts production, employment status, applied material consumption standards, } \\
\text { standards of working time of employees. In economic practice budgeting based on } \\
\text { activity-based costing (ABC) is also used, which allows to evaluate the unit through } \\
\text { processes and activities, and not through the prism of costs incurred in organizational } \\
\text { units. }\end{array}$ \\
\hline $\begin{array}{l}\text { Assessment of operational } \\
\text { efficiency through ac- } \\
\text { counting of responsibility } \\
\text { centers }\end{array}$ & $\begin{array}{l}\text { Responsibility centres in organizations are divisions (segments) that control costs, } \\
\text { revenues, profits and the use of investment funds. The effectiveness of the operation } \\
\text { of responsibility centres is assessed under a specialized form of accounting, i.e. re- } \\
\text { sponsibility accounting using, inter alia, multi-stage and multi-block cost accounting } \\
\text { and available measures of productivity, resource use and effectiveness. The commonly } \\
\text { used measures are: return on invested capital (ROI), surplus result on operating ac- } \\
\text { tivity (RI), return on sales (ROS), EVA index (it is the value that the investment } \\
\text { centre activity "adds" to the enterprise value). }\end{array}$ \\
\hline Balanced Scorecard & $\begin{array}{l}\text { The Balanced Scorecard is an instrument of strategic management which enables the } \\
\text { placement of the company's long-term strategy in the enterprise management sys- } \\
\text { tem through the measurement mechanism [11]. This means that at all levels of the } \\
\text { organization's organization, a specific set of financial and non-financial measures is } \\
\text { used to measure the goals set in four perspectives that implement the mission of the } \\
\text { organization, i.e. in the financial, customer, internal processes and development per- } \\
\text { spectives. For example, these measures may be: in the financial perspective - ROI, } \\
\text { EVA, ROS, in the customer perspective - market share, customer profitability, cus- } \\
\text { tomer satisfaction, customer retention and acquisition, in the perspective of internal } \\
\text { processes - process cost, downtime, number of shortages, development perspective - } \\
\text { satisfaction, productivity, employee turnover, training availability. }\end{array}$ \\
\hline
\end{tabular}


Table 2. Characteristics of selected management accounting tools used in solving decision problems

\begin{tabular}{|l|l|}
\hline $\begin{array}{l}\text { Management account- } \\
\text { ing tool. }\end{array}$ & Characteristics and area of use \\
\hline \multirow{5}{*}{ Capital budgeting } & $\begin{array}{l}\text { Capital budgeting can be defined as a systematic procedure of evaluation and analysis } \\
\text { of investment projects. It is related to strategic planning [11]. In the decision-making } \\
\text { process, capital budgeting models are used which take into account six stages of the } \\
\text { process, namely: project identification, searching for alternative possibilities of the } \\
\text { projects under consideration, obtaining information about projects, project selection, } \\
\text { determining sources of project financing, project implementation, and control of its } \\
\text { implementation. In capital budgeting, decision-makers use capital budgeting tech- } \\
\text { niques (project evaluation measures) taking into account the rate of return or cash } \\
\text { flow estimation, as well as the complex issues of risk estimation and assessment in the } \\
\text { capital budgeting process. }\end{array}$ \\
\hline $\begin{array}{l}\text { System of financial and } \\
\text { non-financial indicators }\end{array}$ & $\begin{array}{l}\text { The ratios used in the financial analysis enable the assessment of the economic and } \\
\text { financial condition of the entity. The source of data for their determination is the } \\
\text { financial statement. Analytical indicators are built for the purposes of controlling } \\
\text { profitability, debt, liquidity and operational efficiency. The formulas for determining } \\
\text { on the subject and in legal regulations. They are a significant help for managers in } \\
\text { planning, decision making, analysis as well as internal and external control. Man- } \\
\text { agers more and more often use computerized management control models that offer } \\
\text { operational and strategic management solutions based on a system of financial and } \\
\text { non-financial indicators (e.g. "President's Dashboard" - a Grant Thorton product, } \\
\text { https://grandthorton.pl). }\end{array}$ \\
\hline
\end{tabular}

* The full characteristics of the above-mentioned models, including their advantages and disadvantages, can be found in the author's article: Kuczyńska-Cesarz A., Koncepcja wybranego rachunku kosztów a procesy decyzyjne w przedsiębiorstwie, Nowoczesne Systemy Zarządzania, Zeszyt 13 nr 4, Wojskowa Akademia Techniczna, Warszawa 2018

** The course of the ABC calculation as well as advantages and disadvantages are described in the article: Kuczyńska-Cesarz A., Rachunek kosztów działań jako narzędzie wspomagające proces zarządzania, Nowoczesne Systemy Zarządzania, Zeszyt 14 nr 1, Wojskowa Akademia Techniczna, Warszawa 2019. Source: own study.

\section{Budgeting in an enterprise versus performance budget in units of the public finance sector}

The budget shows the business unit's action plan, presents the method of allocating resources in the form of quantitative (natural units) and / or value (monetary units), is prepared in the enterprise for a period of one year or shorter ones, adopted (approved) for implementation, applied and implemented with the participation of employees at various levels of management, it is regularly controlled and modified [15]. This definition, among many others in the literature, accurately reflects the essence, tasks, mode and scope of the budget which, with the broadly understood budget control, thanks to which it is possible to determine deviations from the plan, creates a budgeting system in enterprises.

The budget in question is treated as an operational management instrument created in the five-stage budgeting process (I - development of budget assumptions, II - budget preparation, III - budget reconciliation and approval, IV - budget execution correction, $\mathrm{V}$ - reaction to budgeting results) allows for the development of a leading budget consisting of the operational and financial budget. The leading budget with all its components (partial budgets) is a planned photo of the company's activities in the adopted time horizon. Work on its development begins with all activities aimed at estimating the volume and value of sales, which is the basic parameter for creating subsequent budgets, i.e. the production budget and the budget of direct materials related directly to it, direct wages, direct and indirect production costs, general management and sales costs, which in turn allows to prepare a budget for the costs of manufacturing products sold and to determine the level of the planned operating result. All activities performed 
as part of creating the operating budget are possible only when funds are planned for their implementation in the financial budget including pro forma financial statements in a detailed approach to the procedures for constructing the balance sheet, profit and loss account and cash flow statement, taking into account the requirements of the balance sheet law and tax.

While creating partial budgets, various procedures, measures and standards are used, thanks to which it is possible to carry out:

- market analysis, taking into consideration the analysis of individual clients and payment terms for transactions,

- estimating the quantity of products to be manufactured, having in mind the estimation of product inventories at the beginning and end of the period,

- determining the quantity of materials to be purchased using consumption standards,

- estimation based on direct labour budget norms,

- using the cost equation $\mathrm{K}=\mathrm{kz} \cdot \mathrm{x}+\mathrm{Ks}$, (where: $\mathrm{kz}$ - unit variable cost, $\mathrm{x}$ - production volume, $\mathrm{Ks}$ - fixed costs) to estimate fixed costs for the needs of the indirect production costs budget and the indirect management and sales costs budget,

- using the unit cost calculation to create a budget for the manufacturing costs of finished products,

- application of financial reporting procedures to develop the planned profit and loss account at the operational level, planned balance sheet and cash flow statement.

In the current economic reality the leading budget is recognized as a management tool resulting from traditional budgeting based on accounting for the costs of using resources to the places where they arise without linking the costs to the purpose for which they are intended. The allocation of costs to cost objects (products) is made on the basis of calculation methods also referred to as traditional (division, simple, factor, additional calculation). In these methods direct costs are referred to products on the basis of source documents, while indirect costs (management, sales) are settled based on the adopted division keys, which often do not reflect the actual cost involvement in the calculation objects. Traditional budgeting is based on the reporting cost accounting, and all information about costs comes from recording systems and is of a historical cost nature. In the literature on the subject, there is a wide criticism of traditional budgets. For example, the following features determine the disadvantages of this type of budgeting:

- time consuming of their preparation,

- encouragement to rigid planning and thinking in terms of increments and decreases, which does not stimulate rationalization solutions,

- inability to signal rapid changes in a competitive market, hence they are illusory,

- over-reliance on extrapolating past trends,

- no use before the end of the budgetary year for performance assessment, as they signal deviations only at the end of the budgeting period,

- mechanic budget execution control, not conducive to the initiative in creating budgets [15].

Bearing in mind the above, decision makers are looking for new solutions in the area of budgeting. One of them is Activity Based Budgeting (ABB). The method is based on the activity-based costing assuming settlement of costs in a manner different from the methods adopted in traditional cost accounting. Each organization is perceived as a whole of many activities directed at its resources, which becomes the cause of generating costs. The costs are assigned to separate activities, and then, based on the activity cost carriers, they are allocated to cost objects (e.g. products). Therefore, in this cost accounting model, managers have to identify all possible activities in the unit regarding preproduction, production, sales and service areas, administrative areas, determine the costs of these activities and resource cost carriers, determine the unit cost of each activity, and then the unit cost of the object. cost. Example In the unit producing two different products $\mathrm{X}$ and $\mathrm{Y}$, direct costs (consumption of direct materials, direct wages, other direct costs) were identified and assigned on the basis of source documents to manufactured products (the production volume of $\mathrm{X}$ and $\mathrm{Y}$ is known), and the amount of budgeted indirect costs was determined accounted for products $\mathrm{X}$ and $\mathrm{Y}$ and two cost-generating activities were distinguished - machine setting and material operations. Calculation of the unit cost of products $\mathrm{X}$ and $\mathrm{Y}$ using the Activity Based Costing $(\mathrm{ABC})$ method will include the following activities: 
- assigning indirect costs related to selected activities from the total budgeted indirect costs,

- determining the cost carrier of activities (for machine setup - number of setups for each product, for material operations - number of material operations for $\mathrm{X}$ and $\mathrm{Y}$ ),

- calculation of the unit cost of selected activities (cost of the activity / volume of the activity cost carrier),

- determination of the cost of an activity per unit of products $\mathrm{X}$ and $\mathrm{Y}$ (unit cost of the activity · volume of the cost of the activity / production volume),

- determination of the unit cost of products X and Y (the sum of unit calculation items relating to direct and indirect costs, settled individually for separate activities and products).

In the public sector units difficulties are noticeable with defining the effects of public service implementation. ABC is the easiest way to assess effectiveness by identifying activities and measuring the costs they generate with the use of effectiveness measures adopted in management control procedures [8].

The budgeting procedure based on the ABB account runs in the reverse order than in the activity-based costing method, which is shown in fig. 4 .
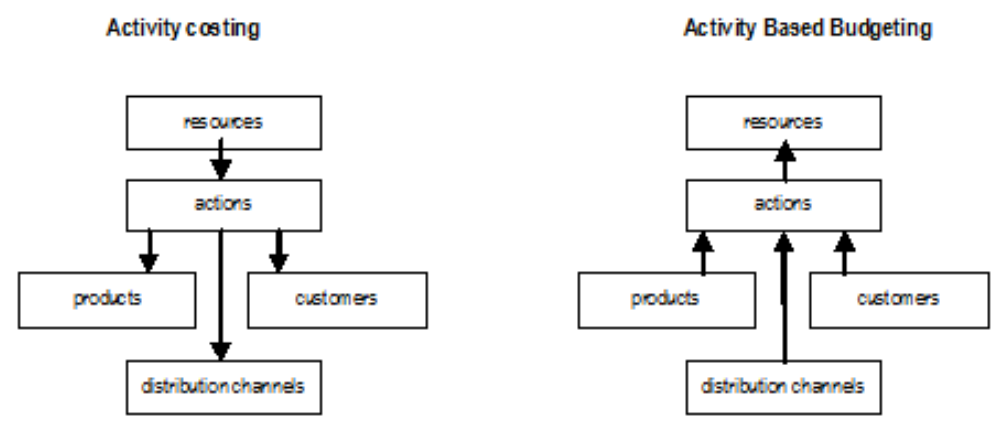

Figure 4. The concept of budgeting based on cost accounting

Source: Rachunkowość zarządcza i rachunek kosztów t. II, praca zbiorowa pod red. G. K. Świderskiej, Difin, Warszawa 2003, pp. 11-60.

Thus, the budgeting stages include work on:

- estimating the volume of production and sales for individual products and customers - similar to traditional budgeting,

- estimating activities and demand for activities through the activity cost drivers,

- determining the demand for resources to carry out planned activities within specific processes,

- determining the overall quantity and value of resources that should be provided to meet the demand for process activities,

- taking actions adjusting the size of the needed resources to their supply by determining the actual capacity to act resulting from the resource capacity,

- determining the costs of unused activities and resources [14].

The new approach to cost budgeting is conducive to increasing the efficiency of using all resources involved in achieving the planned goals and tasks in entities conducting business activity.

In units operating in the public finance sector, as in enterprises, new solutions in the field of budgeting are being introduced on an increasing scale, making it possible to link goals with the effectiveness of managing resources. One of such solutions is the performance budget. A performance budget is a budget expenditure plan drawn up in the structure of functions, tasks and subtasks along with an indication at the level of tasks and subtasks of goals that are planned to be achieved as a result of the implementation of the task (subtasks) and measures defining the degree of goal achievement [2]. It follows from this definition that the performance budget includes budget expenditures in 
accordance with the task classification, and not with the budget classification as so far, which means the need to define in detail tasks financed from budgetary funds and to use specific measures used to assess the effects obtained. Hence, an obligatory part of the performance budget is additionally attached to the fitness part, in which goals and measures are assigned to each implemented task, allowing to assess the effectiveness of achieving goals. An example of a measure of effectiveness in the performance budget is shown in fig. 5 .
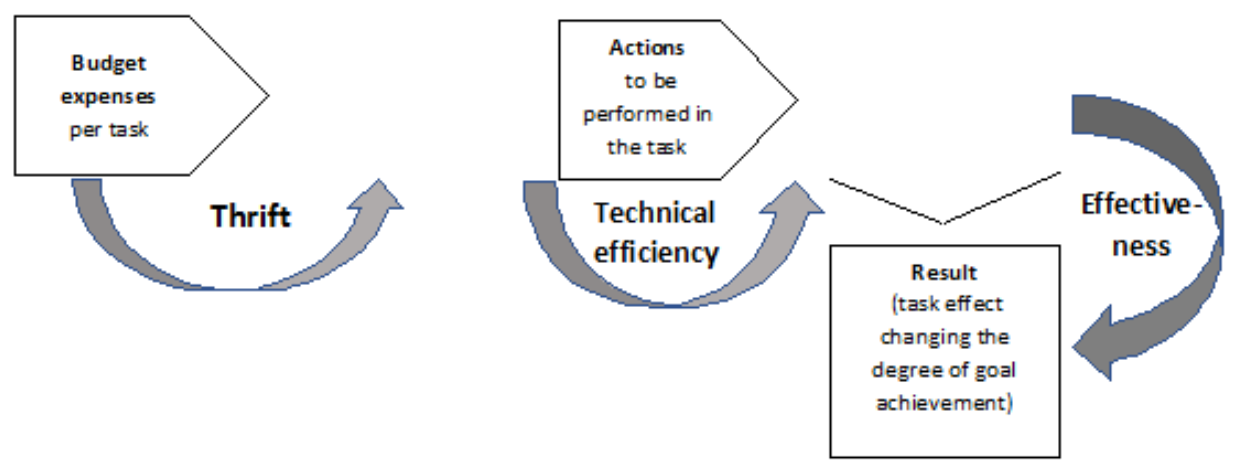

Figure 5. Measurement of effectiveness in the performance budget

Source: Nucińska J., Budżet zadaniowy jako narzędzie pomiaru skuteczności działania wybranych jednostek samorządu terytorialnego, Nierówności Społeczne a Wzrost Gospodarczy, nr 56 (4/2018), Uniwersytet Rzeszowski, Rzeszów 2018, p. 353.

Currently, the Public finance act (Journal of Laws of 2019, item 869, art. 40) allows local governments to develop their own budget in the form of a task. Traditional budgeting in public finance units is based on the applicable budget classification that allows for a detailed breakdown by sections, chapters and paragraphs of income and expenditure as well as income and expenditure. It is closely related to the Chart of Accounts (PK) or the Company Chart of Accounts (ZPK) used in the accounting records [8].

The budget classification is thus treated as an instrument through which public funds are described. The performance-based budget imposes the obligation to include expenditure in terms of the tasks carried out, taking into account various spheres of activity (functions). By carrying out tasks, goals and effects are achieved, measured by the system of available measures specified in the fitness part of the budget. Performance budget in public sector units is linking its resources with specific products, e.g. maintenance of a square meter of road. The tasks to be carried out in this area may include: renovation of the surface, emptying the street litter, cleaning underground passages, the cost of removing or maintaining the tree, the cost of unblocking $1 \mathrm{~m}$ of the current drainage ditch, street lighting. The measure of the effectiveness of the implementation of these tasks will be the unit cost index used in planning practice $[2]$.

Budgeting based on activity-based costing and task-based budgeting as tools supporting the management process used in solving decision problems have much in common, although they are used in organizations pursuing various statutory goals. Combining goals with tasks and the efficiency of using resources in both tools is presented in fig. 6 .

\section{Conclusions}

Without an accounting system, it is difficult to imagine the management of diverse organizations operating in the Polish economy. The resource of various information provided by the financial accounting system, processed and used for the purposes of management accounting, enables the creation of numerous instruments used by decisionmakers in making important decisions having a direct impact on the status of the organization in the future. The wide range of selected management instruments presented in this article - safety engineering tools for anthropogenic objects, makes it possible to adapt them to a specific problem situation taking place in a given unit. The form of operation of the organization does not matter, it is important to define the goal to be achieved by the managers, determine the possibility of its implementation, prepare for implementation and use appropriate instruments offered 
- Sales volume estimation

- Estimating the demand for activities generating costs of the conducted adivity

- Defining resource cost measures and activity cost measures

- Determining the quantity and value of resources to implement the activities

- Assigning responsibility for the performance of budgeted tasks to appropriate units

- Taking actions to adjust the size of resources to the needs of tasks - assessment of the costs of unused adivities and resources

- Budget execution control, effediveness assessment
- Estimating the demand for local government services

- Determining the financial capacity

- Defining goals for assigned tasks and assigning units responsible for their execution

- Establishing task costs

- Defining the measures for measuring the effectiveness of achieving the goals for the defined tasks

- Monito ring of budgeted activities

- Analysis and evaluation of the degree of task implementation and the achieved efficiency indicators

Figure 6. Common features of activity-based and performance-based budgeting

by management accounting. A commonly used management tool is budgeting (traditional and based on activity-based costing) and task-based budgeting used in enterprises and public finance sector units. Thanks to it, it is possible to link planned tasks with resources and the efficiency of their use. A detailed description of the stages of budget creation, implementation, implementation and control of its implementation is included in the budgeting procedures available to managers in the literature on the subject and in internal regulations created for the needs of a specific organization. It can be said with certainty that management accounting instruments treated as tools for engineering anthropogenic objects allow organizations to overcome difficulties accompanying problem situations in functioning in the present and in the near and distant future.

\section{References}

1. Baryłka, A. Problemy Inżynierii bezpieczeństwa obiektów antropogenicznych. Centrum Rzeczoznawstwa Budowlanego tom I, 5-6 (2019).

2. Definiowanie celów i mierników na potrzeby budżetowania zadaniowego, BUDŻET-ZADANIOWY.COM 2010 http:/budzet-zadaniowy.com/baza_miernikow.

3. Dobija, M. Rachunkowość zarządcza i controlling 63-65 (Wydawnictwo naukowe PWN, Warszawa, 1999).

4. Kuczyńska-Cesarz, A. Koncepcja wybranego rachunku kosztów a procesy decyzyjne w przedsiębiorstwie, Nowoczesne Systemy Zarzadzania, Zeszyt 13, Wojskowa Akademia Techniczna, Warszawa 4 (2018).

5. Kuczyńska-Cesarz, A. Rachunkowość kreatywna a bezpieczeństwo informacji zawartych w sprawozdaniu finansowym. Nowoczesne Systemy Zarzadzania, Zeszyt 13, Wojskowa Akademia Techniczna, Warszawa 1 (2018).

6. Kuczyńska-Cesarz, A. Rachunek kosztów działań jako narzędzie wspomagające proces zarządzania, Nowoczesne Systemy Zarzadzania, Zeszyt 14, Wojskowa Akademia Techniczna, Warszawa 1 (2019).

7. Kuczyńska-Cesarz, A. Wykorzystanie analizy finansowej w procedurach audytu zewnętrznego. Modern Engineering 2 (2020).

8. Kuczyńska-Cesarz, A. \& Szczerbak, M. Narzędzia rachunkowości podstawa stabilności sektora finansów publicznych, 55,97 (Difin, Wraszawa, 2020).

9. Nucińska, J. Budżet zadaniowy jako narzędzie pomiaru skuteczności działania wybranych jednostek samorządu terytorialnego. Nierówności Społeczne a Wzrost Gospodarczy, Uniwersytet Rzeszowski, Rzeszów 56, 353 (4 2018).

10. Obolewicz, J. Analiza realizacji procesu inwestycyjnego na przykładzie obiektu budowlanego - Archiwum Państwowego w Białymstoku. Część 1. 2019.

11. Peterson, R. Kompendium terminów z zakresu rachunkowości po polsku i angielsku, mf.gov.pl, Warszawa, 2015.

12. Szczypta, P. Rachunkowość zarzadcza - klucz do sukcesu 13,137 (CeDeWu Sp. z o o., Warszawa, 2014 ).

13. Ustawa o finansach publicznych - tekst jednolity (Dz. U. z 2019, poz. 869). 2019. 
14. Rachunkowość zarządcza i rachunek kosztów t. II, praca zbiorowa (ed Świderska, G.) 10-1, 11-60, 11-61, 13-1 (Difin, Warszawa, 2003).

15. Controlling kosztów i rachunkowość zarządcza - praca zbiorwa (ed Świderska, G.) 288, 459-460 (Difin, Warszawa, 2010). 